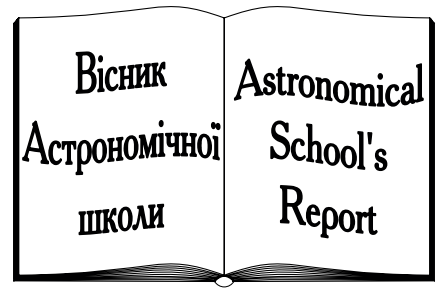

ISSN 1607-2855

Том 5 • № $1-2 \cdot 2004 \quad$ C. $242-245$

UDC 520.2.07

\title{
Automatic telescope for observation of near-Earth asteroids
}

\author{
V.V. Rumyantsev, N.S. Chernykh
}

Crimean Astrophysical Observatory

The old 64-cm Richter-Slefogt telescope $(F=90 \mathrm{~cm}$ ) of the Crimean Astrophysical Observatory was reconstructed and equipped with the ST-8 CCD camera supplied by The Planetary Society as the Eugene Shoemaker Near Earth Object Grant. The first observations of minor planets and comets were made with the telescope in 2000. The CCD matrix of ST-8 camera in the focus of our telescope covers field of 52.7' $\times 35.1^{\prime}$. With 120-second exposure we obtain the images of stars up to the limiting magnitude of 20.5 mag within $S / N=3$. The first phase of automation of the telescope was completed in May 2002. According to our estimations, the telescope will be able to cover the sky area of 20 square deg with threefold overlapping during the night. The software for object localization, image parameters determination, stars identification, astrometric reduction, identification and cataloguing of asteroids is worked up. The first observation results obtained with the 64-cm CCD telescope are discussed.

АВТОМАТИЗАЦІЯ ТЕЛЕСКОПА ДЛЯ СПОСТЕРЕЖЕНЬ АСТЕРОЇДІВ, ЩО НАБЛИЖАЮТЬСЯ ДО ЗЕМЛI, Румяниев В.В., Черних М.С. - У Кримсъкій астрофізичній обсерваторії було відновлено 64-см телескоп Pихтера-Слефогта $(F=90 \mathrm{cм})$ за фінансової підтримки Інституту теоретичної астрономії й Міжнародного Інституту проблем астероӥдної небезпеки (Санкт-Петербург, Росія) с метою проведення регулярних масових спостережень астероїдів, шо наблиюаються до Землі. В травні 1999 року було проведено перші спостереження в первинному фокусі з ПЗЗ ST-8 (13.8×9.2 мм, $9 \times 9$ мкм/niкс, 52.7' $\times 35.1^{\prime}$, $S B I G, C \amalg A)$, отриманим від Американсъкого Планетного товариства. При спостережсенні вибраної ділянки $S A-57$ за 120 с експозииї̈ були зареєстровані зорі 20.5 зор.вел. з $S / N=3$. Більшість зоряних зображень покривають $2 \times 2$ пікселя. Периа стадія автоматизачї̈ телескопу завериилась в травні 2002 p. На телескопі було замінено крокові двигуни та виготовлено новий блок керування ними. Згідно з першим пробним спостереженням, телескоп здатен покривати область неба в 20 квадратних градусів з потрійним перекриванням протягом ночі. Створено й налагоджуєтвся програмне забезпечення для локалізацї об'єктів, визначення параметрів зображення, ідентифікачії зірок, астрометричної редукиії, ідентифікаиії та каталогізацї̈ астероїдів. Обговорюються перші результати спостережень, отримані з 64-см ССD телескопом.

АВТОМАТИЗАЦИЯ ТЕЛЕСКОПА ДЛЯ НАБЛЮДЕНИЙ АСТЕРОИДОВ, СБЛИЖАЮЩИХСЯ С ЗЕМЛЕЙ, Румяниев В.В., Черных Н.С. - В Крымской астрофизической обсерватории был восстановлен 64-см телескоп Pихтера-Слефогта (F=90 cм) при финансовой поддержке Института теоретической астрономии и Международного Института проблем астероидной опасности (С.-Петербург, Россия) с целъю проведения регулярных массовых наблюдений астероидов, сближающихся с Землей. В мае 1999 были проведены первые наблюдения в первичном фокусе с ПЗС ST-8 $(13.8 \times 9.2$ мм. $9 \times 9$ мкм/nuк, 52.7' × 35.1', SBIG, США) полученной от Американского Планетного общества. При наблюдении избранной области $S A-57$ за 120 сек экспозичии были зарегистрированы звезды 20.5 зв.вел. с $S / N=3$. Большинство звездных изображений покрывают 2×2 пикселя. Первая стадия автоматизации телескопа была закончена в мае 2002. На телескопе были заменены шаговые двигатели и изготовлен новый блок управления ими. Согласно первым пробным наблюдениям, телескоп способен покрывать область неба в 20 квадратных градусов с тройным перекрыванием в течение ночи. Создано и отлаживается программное обеспечение для локализачии объектов, определения параметров изображения, идентификаиии звезд, астрометрической редукиии, идентификации и каталогизаиии астероидов. Обсуждаются первые результаты наблюдения, полученные с 64-см CCD телескопом.

Crimean program of observing Near Earth Asteroids is a logical continuation of the photographic review of minor planets conduct in the Crimean Astrophysical Observatory (CrAO) since 1963 to 1997 [1]. In 1993 the work was started according to the initiative of A.G.Sokolsky and N.S.Chernykh on the reconstruction of old $64-\mathrm{cm}$ telescope in order to use it for observing of the asteroids, approaching to the Earth. 
Table 1.

\begin{tabular}{|l|l|}
\multicolumn{2}{c}{ Table 1. } \\
\begin{tabular}{|l|l|}
\hline \multicolumn{1}{c}{ ST-8 } \\
\hline CCD size & $1530 \times 1020$ \\
Area & $13.8 \times 9.2 \mathrm{~mm}$ \\
Field of view & $52.7^{\prime} \times 35.1^{\prime}$ \\
Pixel & $9 \mu$ \\
Well Depth & $80 \mathrm{Ke}$ \\
Digital resolution & $16 \mathrm{bit}$ \\
Dark signal & $36 \mathrm{e} / \mathrm{min} \cdot \mathrm{pix} @ 0^{\circ} \mathrm{C}$ \\
Read noise & $15 \mathrm{e}^{-1}$ \\
\hline
\end{tabular}
\end{tabular}

Table 2. Limit magnitude with CCD

64-cm telescope of Richter-Slefogt system was designed and built by the German company Carl Zeiss Jena during the Second World War. Telescope has a spherical mirror of diameter $D=675 \mathrm{~mm}$ and focal length $905 \mathrm{~mm}$. Correction system consists of two lenses of diameter $643 \mathrm{~mm}$.

Flat surface of second lens has an aluminum covering of diameter $285 \mathrm{~mm}$ and serves a secondary mirror, shortening an optical system. Focal length of the whole system is $894 \mathrm{~mm}$. Field of view is $80 \mathrm{~mm}$ and has a radius of curvature $90 \mathrm{~cm}$. Flat field correction lens, installed before focal surface, ensures a flat field of diameter $60 \mathrm{~mm}$ (4 degrees) and shortens an equivalent system focal length to $F=822 \mathrm{~mm}$. Focal surface is inside the tube, on the distance of $35 \mathrm{~cm}$ from back edge of the cassette tube.

In March 1999 we have got CCD camera SBIG St-8 for a grant of the American Planetary Society, given to us in October 1997 for the developing of the ITA-CrAO observing program. Its main features are presented in the table 1 .

Limiting magnitude registered by CCD telescope, depends on acting area of telescope, technical features of CCD matrixes, time of accumulations and background of the sky and it can be determined by following expression:

$$
m=7.1+0.5 \mu+2.5 \lg \frac{\sqrt{S \eta T}}{k \Delta}
$$

where $S$ - effective area of telescope in sq.cm., $\eta$ - quantum efficiency of CCD matrix, $T-$ exposure in seconds, $\Delta$ - side of square of number of elements, covered by image of the star on matrix in arcsecond, $k$ - signal to noise ratio, $\mu$ - brightness of the sky background in stellar magnitudes for square arcsecond. Considering constructive particularities of the optical system of our telescope and taking the values $\mu=21.0^{\mathrm{m}} / \mathrm{sq}$.arcsec, $\eta=0.4, k=5, \Delta=4$, one find the values of limiting magnitude depending on exposures (table 2):

In May of 1999 we had begun the first test observations with the matrix ST-8, installed in the

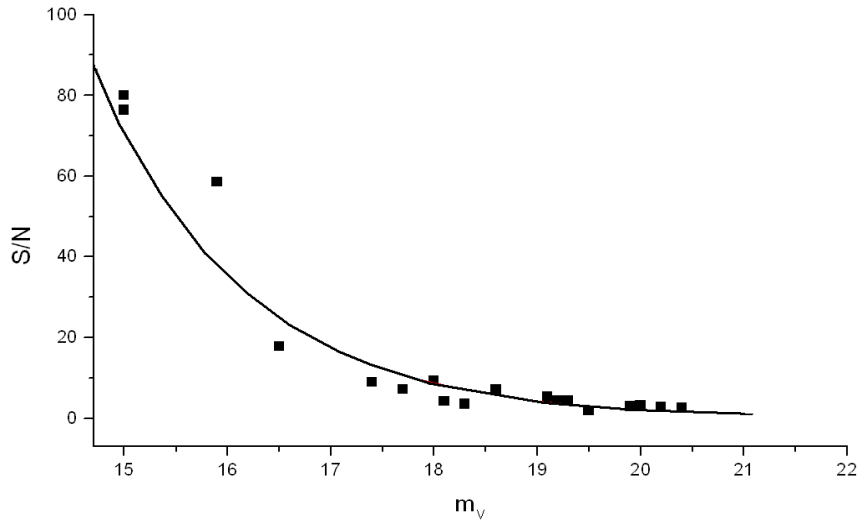

Fig. 1. Dependence of relations $\mathrm{S} / \mathrm{N}$ on magnitude for 2 minute exposures

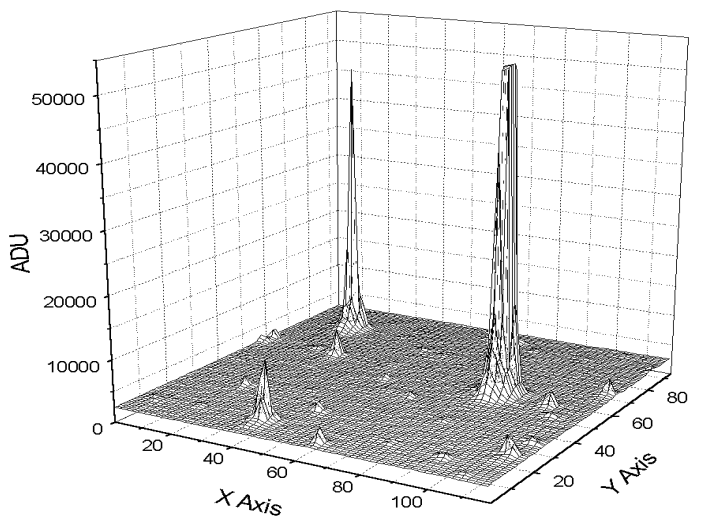

Fig. 2. Fragment of frame $3^{\prime} \times 4^{\prime}$ 
Table 3. Accuracy of astrometric observations of some objects

\begin{tabular}{|l|c|c|c|c|}
\hline Object & Number & Period of observation & $\begin{array}{c}\sigma \alpha \\
\text { (arcsec) }\end{array}$ & $\begin{array}{c}\sigma \delta \\
(\operatorname{arcsec})\end{array}$ \\
\hline C/1999 H1 & 6 & $08.11 .1999-10.11 .1999$ & 0.4 & 0.2 \\
C/1999 J2 & 6 & 16.07 .2000 & 0.4 & 0.4 \\
2000 NM (Motion $\left.=10^{\prime \prime} / \mathrm{min}\right)$ & 64 & $04.07 .2000-28.07 .2000$ & 0.1 & 0.3 \\
1999 KW4 (Motion $\left.=45^{\prime \prime} / \mathrm{min}\right)$ & 36 & 24.05 .2001 & 0.4 & 0.4 \\
\hline
\end{tabular}

Table 4. Possible number of Near Earth Asteroids of corresponding limiting magnitude

\begin{tabular}{|l|c|c|c|c|c|c|}
\hline Limiting magnitude V & 16 & 17 & 18 & 19 & 20 & 21 \\
\hline Number of NEA & 0.3 & 0.7 & 1.8 & 4.6 & 11.7 & 22.5 \\
\hline
\end{tabular}

primary focus of the telescope. We found that limit magnitude for stars is $20.5^{m}$ with for exposure of 2 minutes that is in well agreement with theoretical evaluations. Fig. 1 presents values of a signal to noise ration $S / N$ for stars of field. Limit magnitude was estimated from observations of selected areas SA 51 and SA $57[2]$.

Telescope gives image of the stars of the diameter $2 \sigma=18 \mu$, that corresponds to an area of $2 \times 2$ pixels. Fragment of frame $3^{\prime} \times 4$ with the stars of different brightness is shown on fig. 2 .

Evaluation of an overexposed stars shows that stars brighter then $11.7^{m}$ cause an overflow of charge in pixels. Amount of the overexposed stars in the frame can be several dozens.

V.V.Rumyantsev had developed a software AstroMet ver.1.2 that allows to make a preliminary image preprocessing, localization of the registered stars, determination of parameters of image of stars and astrometric and photometric reduction. Profiles of star are presented by the fixed Gauss model functions [3]

$$
D_{x_{i}, y_{i}}=a_{1}+a_{4} \exp \left\{-\frac{1}{2\left(1-a_{9}^{2}\right)}\left[\left(\frac{x_{i}-a_{5}}{a_{6}}\right)^{2}+\left(\frac{y_{i}-a_{7}}{a_{8}}\right)^{2}-2 a_{9}\left(\frac{x_{i}-a_{5}}{a_{6}}\right)\left(\frac{y_{i}-a_{7}}{a_{8}}\right)\right]\right\}
$$

Here $a_{1}$ refers to local background density, $a_{4}$ describes peak density in image, $a_{5}$ and $a_{7}$ describe image center coordinates and $a_{6}, a_{8}$ and $a_{9}$ describe the axis and orientation of general elliptical figure of star image.

From June 2000 to July 2002 first working observations of several asteroids (including NEA 2000 NM, 1999 KW4 and 2002 NX) and comets were carried out (Fig. 3). Simultaneously the work on the improving of the software and developing of the methods of observation was made. Altogether about 2500 frames were received. At present the work on automations of telescope and the improvement of programs of image processing is in progress.

Accuracy of astrometric observations of some objects is present in the table 3 .

Telescope productive capacity, i.e. area of the sky covered by the observations for unit of time for the fixed limiting magnitude, depends strongly on degree of automations of telescope.

At the beginning of 2002 year the first phase of automation of telescope was ended. We replaced an old stepper motors by faster ones and installed the motion controller, which permits us to operate by telescope from computer. Without angle encoders, we can control telescope position by calculating number of steps of motors. Telescope modernization allows us to raise covering sky area to 10 sq.degrees per hour. This productivity is limited only by readout time of CCD and can be improved by replacing CCD camera by new one, with more large area and faster readout time. We haven't enough financial support now for this update. Additional feature of the new controller is the capability to follow fast moving objects with angular velocity up to 120 arcsec per second. For average 6-hours night it is possible to get 100-120 frames, or 15 000-18000 frames per year. It corresponds to 2500-3000 square degrees per year for the triple overlapping of observed areas. Probability of discovery of the NEAs in such area of the sky during a year is evaluated according to the results of E.Helin and R.Dunbar [4]. Possible number of Near Earth Asteroids of corresponding limiting magnitude is presented by the table 4 .

For the comparison let us note that known program with the Spacewatch telescope of the Observatory 


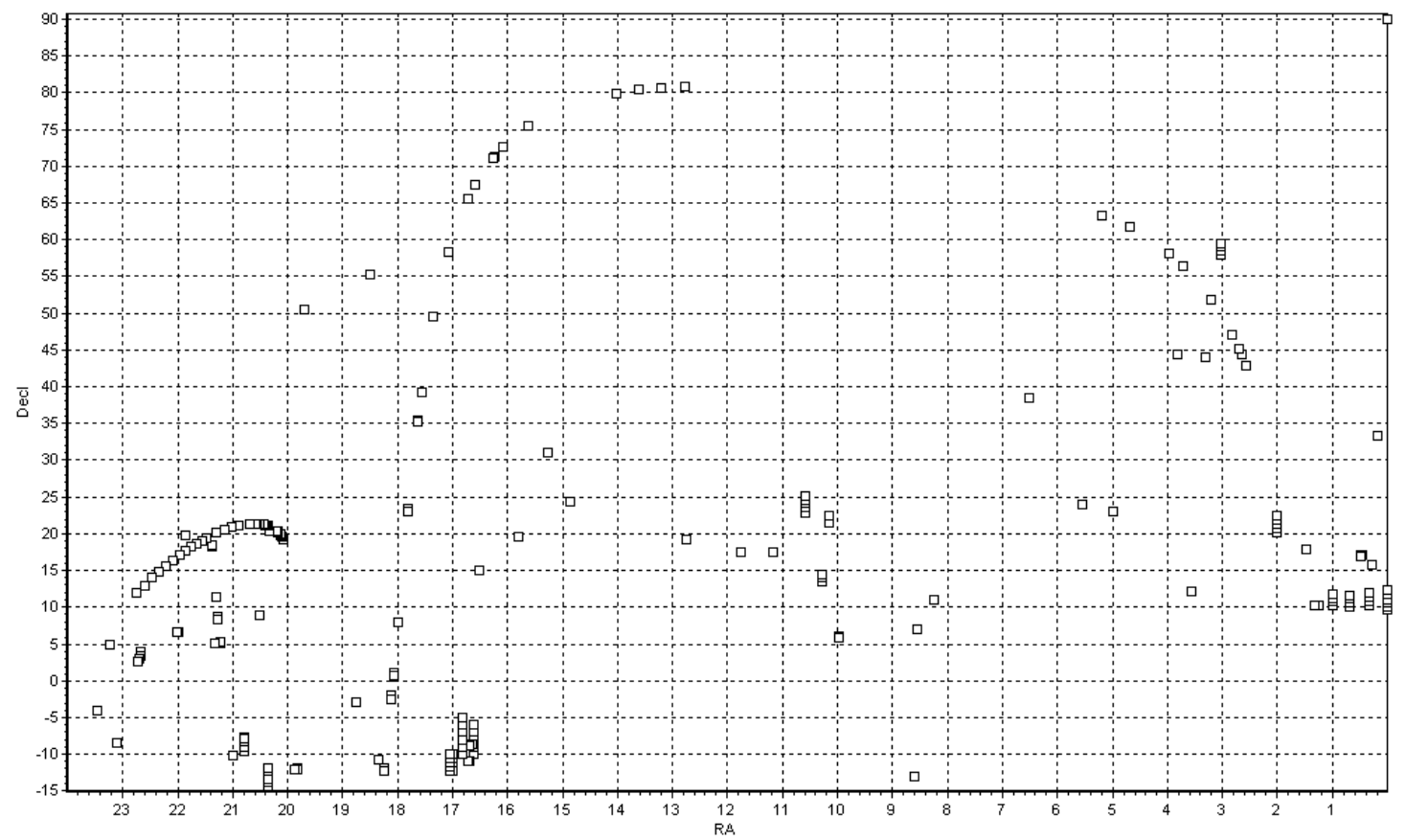

Fig. 3. The positions of frames observed from June 2000 to July 2002

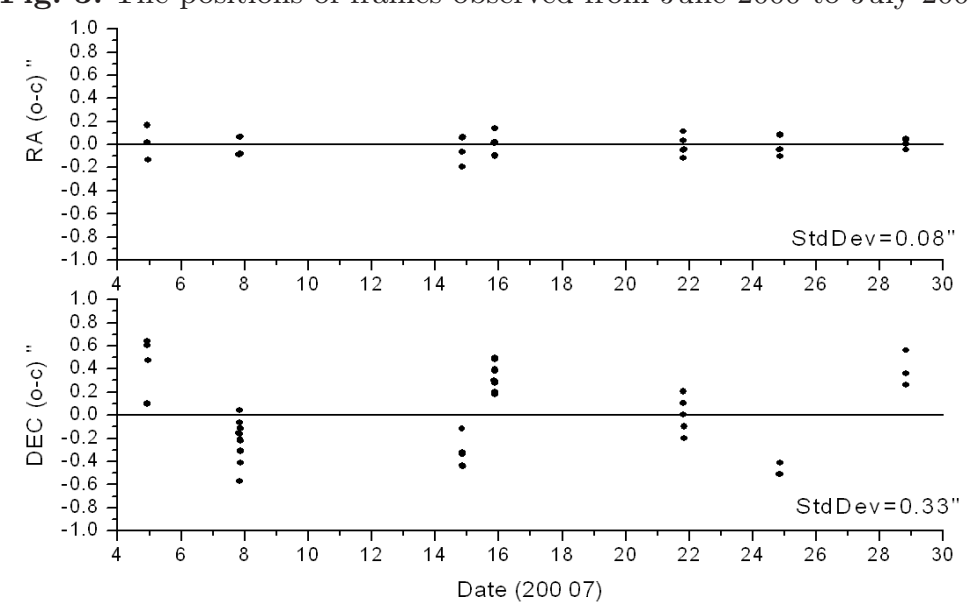

Fig. 4. Residuals of observed positions of asteroid $2000 \mathrm{NM}$

Kitt Peak, using a method of scan when observing, gets at the average 1250 square degrees per year under the triple overlapping of observed areas and registers near 20000 asteroids to $21^{\mathrm{m}}$.

1. Chernykh N.S. Crimean minor planet survey: Dissertation...for Dr. Sc. Degree. - S.-Petersburg, 1999. (in Russian)

2. Everhart E. Finding Your Telescope's Magnitude Limit // Sky \& Telescope. — 1984. — 77, № 1.

3. Sanders W.L., Schroder R. Membership in the cluster NGC 6494 // Astron. Astrophys. - 1980. - 88, № 1/2. - P. 102-107.

4. Helin E., Dunbar R. Search techniques for near-Earth asteroids // Vistas in astronomy. - 1990. - 33. P. 21-37.

Received 9.09.2004 